\title{
Cross-group neutralization of HIV-1 and evidence for conservation of the PG9/PG16 epitopes within divergent groups of HIV-1
}

\author{
M Braibant ${ }^{3}$, E Gong $^{3}$, J Plantier ${ }^{1}$, F Simon ${ }^{2}$, F Barin $^{3 *}$ \\ From AIDS Vaccine 2012 \\ Boston, MA, USA. 9-12 September 2012
}

\section{Background}

HIV-1 has been classified into 4 groups: $\mathrm{M}, \mathrm{N}, \mathrm{O}$ and $\mathrm{P}$. The aim was to revisit the cross-group neutralization using a highly diverse panel of primary isolates (PI) and human monoclonal neutralizing antibodies (mAb).

\section{Methods}

The panel of viruses included 9 HIV-1 group O PIs, 1 recombinant M/O PI, 1 group N PI, 1 group P PI, 2 group $M$ (subtype $B$ ) PIs and the HIV-1 group $M$ adapted strain MN. All the viruses were tested for neutralization in TZM-bl cells, using a panel of sera issued from patients infected by HIV-1 group $M$ viruses $(n=11)$, HIV-1 groups $\mathrm{O}(\mathrm{n}=12)$ and $\mathrm{P}(\mathrm{n}=1)$. The mAbs were b12, 2G12, 2F5, 4E10, PG9, PG16, VRC01, VRC03 and $\mathrm{HJ} 16$.

\section{Results}

The 12 group $\mathrm{O}$ sera neutralized from 1 to 6 group $\mathrm{O}$ viruses, and 6 of them cross-neutralized one group M PI. Five of the 10 group $M$ sera cross-neutralized from 4 to 9 group O PIs. The group N and P viruses were neutralized by 1-4 of 12 and 4-5 of 11 sera from groups $O$ and $M$ patients, respectively. The human mAbs did not show any cross-group neutralization, except PG9 and PG16. Two group O PIs were neutralized by both PG9 and PG16, and one group O PI was neutralized by PG9 only. The group N PI was highly sensitive to neutralization by PG9 and PG16. The N-linked glycans at positions 156 and 160 and the cationic residues of strand $\mathrm{C}$ of the $\mathrm{V} 1 / \mathrm{V} 2$ domain that have been identified as part of the PG9 epitope are conserved among the group $\mathrm{N}$.

Universite François Rabelais, and INSERM U966, Tours, France

Full list of author information is available at the end of the article

\section{Conclusion}

The cross-group neutralization of HIV-1 has been demonstrated. The conservation of the PG9 and PG16 epitopes between groups provides an argument for their relevance as components of a potentially efficient HIV vaccine.

\section{Author details}

'Charles Nicolle University Hospital, Rouen, France. ${ }^{2}$ St Louis Hospital, Paris, France. ${ }^{3}$ Universite François Rabelais, and INSERM U966, Tours, France.

Published: 13 September 2012

doi:10.1186/1742-4690-9-S2-P53

Cite this article as: Braibant et al:: Cross-group neutralization of HIV-1 and evidence for conservation of the PG9/PG16 epitopes within divergent groups of HIV-1. Retrovirology 2012 9(Suppl 2):P53.

Submit your next manuscript to BioMed Central and take full advantage of:

- Convenient online submission

- Thorough peer review

- No space constraints or color figure charges

- Immediate publication on acceptance

- Inclusion in PubMed, CAS, Scopus and Google Scholar

- Research which is freely available for redistribution 